\title{
Innovative Approach to Evaluation of the Decoupling Phenomena in Making Decision on Investment of Agro-Business
}

\author{
Alla Tkachenko, Nataliia Levchenko, Tatyana Pozhuieva, Nataliia Chupryna
}

\begin{abstract}
The author's suggestions for improving the method of assessing the effectiveness of the implementation of state environmental policy of the country by supplementing the list of common environmental performance indicators, indicators of the decoupling phenomenon, which are based on indicators of economic growth in both the country as a whole and individual industries are presented in the article. Implementation of these proposals in practice will ensure that the government makes clear and prudent decisions about increasing agricultural production, saving the environment and using natural resources to meet the modern needs of mankind and the interests of future generations in food security, safety and health.
\end{abstract}

Keywords: decoupling, impact decoupling, resource decoupling, gross agricultural production

\section{INTRODUCTION}

In the face of aggravated global food and climate change the agrarian business of Ukraine with its powerful potential and favourable natural and climatic conditions opens ample opportunities. Therefore, agrarian business should be recognized as one of the most promising areas of business in Ukraine in the light of these problems. Therefore, a number of strategic documents and regulations have been adopted in order to make the country a strong and independent government of Ukraine that creates the foundations for the economic development of agricultural production. Among them, special attention is paid to "Agrostrategy-2030", which is expected in the next decade to create Ukraine a world food supermarket and an organic hub [1].

Today, Ukraine is in the first place in the world food market in sunflower oil, fourth in corn and barley, fifth in wheat, and so on. [2]. According to the results of 2018, the share of agricultural production in GDP is over $10 \%$. According to estimates by experts of the Ukrainian Institute of the Future (UIF) and Latifundist Media, it is expected to increase to $17 \%$ in the next decade, with an increase in GDP

Revised Version Manuscript Received on October 15, 2019.

Alla Tkachenko, Dr. of Economic sciences, Professor, the Head of the Department of Entrepreneurship, Trade and Exchange activities, "Zaporizhzhia Polytechnic" National university, Zaporizhzhia, Ukraine

Nataliia Levchenko, Dr. state management, Professor at the Department of Entrepreneurship, Trade and Exchange activities, "Zaporizhzhia Polytechnic" National university, Zaporizhzhia, Ukraine

Tatyana Pozhuieva, Dr. of Economic sciences, Professor, the Head of the Department of Management and Finance, Ukrainian State University of Chemical Technology, Dnipro, Ukraine

Nataliia Chupryna, Cand. of Economic sciences, Assistant Professor, Dean of the faculty of the Economics, Ukrainian State University of Chemical Technology, Dnipro, Ukraine problem, intensifying the search for ways to solve them for

by $\$ 80$ billion and an increase in budget revenues by $\$ 15$ billion [1].

However, it should be remembered that the increase in agricultural production is accompanied by environmental threats, which requires the government to ensure a balanced environmentally-oriented development of agrarian business, and thus to meet the interests of future generations in food security and reduce environmental sustainability.

It is possible to estimate the rate of depletion of an ecosystem with the increase in agricultural production due to the effect of decoupling (from English decoupling is demarcation, separation, separation, disruption of communication) [13], which undoubtedly makes the study of the method of its assessment quite relevant.

\section{METHOD}

Construction of statistical data on capital investment dynamics due to correlation-regression analysis and output of gross output of agricultural non-linear multiple dependence of $\mathrm{CO}_{2} \mathrm{eq}$ emissions into the atmosphere from stationary sources of pollution of agribusiness.

\section{LITERATURE REVIEW}

For the first time, the concept of "decoupling" was used by the Organization for Economic Co-operation and Development (OECD) in the program document "An Environmental Strategy for the First Decade of the $21^{\text {st }}$ Century" (2001), and meant a disconnect between "negative environmental impact" and "economic benefits" [13]. It has been used to this end in Thematic Strategy on the sustainable use of natural resources (2005) [18] and in Roadmap to a Resource Efficient Europe (2011) [15].

However, with the Assessment of resource efficiency indicators and targets (Final report - 2012) [5] and with the launch of the UNEP Decoupling Natural Resource Use and Environmental Impacts from Economic Growth [8] report, the concept of "decoupling" has become more widely interpreted, namely as a key principle of the inconsistency of traditionally formed interconnected processes of development of economic growth, volumes of consumed natural resources and pollution of the environment, which provides for meeting the growing needs of society while minimizing the consumption of natural capital [8]. 
In domestic practice, the concept of "decoupling" is not widely used because of the meagre amount of its studies. And so, interpretations of its content component by domestic scholars mainly rely on the etymology of the borrowed English-speaking term (Table 1):

Table 1: Interpretation of the definition of "decoupling"

\begin{tabular}{|c|c|}
\hline Author & Content component \\
\hline Barzhyna A. [3] & $\begin{array}{l}\text { decoupling is the phenomenon of the } \\
\text { difference between economic growth and } \\
\text { reducing the pressure on the environment }\end{array}$ \\
\hline $\begin{array}{l}\text { Vatchenko O. } \\
\text { Svystun K. [6] }\end{array}$ & $\begin{array}{l}\text { decoupling is breaking the link between the } \\
\text { growth of economic volumes or rates and the } \\
\text { increase in volumes or rates of exploitation } \\
\text { of resources or harmful anthropogenic load } \\
\text { on the environment and human health }\end{array}$ \\
\hline $\begin{array}{c}\text { Veklych O. } \\
\text { Danylyshyn B. } \\
\text { [7] }\end{array}$ & $\begin{array}{l}\text { decoupling is a process of sustained } \\
\text { long-term, projected and managed mismatch } \\
\text { in economic growth trends, consumption of } \\
\text { natural resources and environmental } \\
\text { pollution at all stages of the life cycle. }\end{array}$ \\
\hline Zabelyna Y. [9] & $\begin{array}{l}\text { decoupling implies an increase in output } \\
\text { while reducing environmental pressure on } \\
\text { the environment }\end{array}$ \\
\hline $\begin{array}{c}\text { Kokovskyi L. } \\
\text { [11] }\end{array}$ & $\begin{array}{l}\text { decoupling is the delimitation of the use of } \\
\text { natural resources from economic growth and } \\
\text { the delimitation of the environmental impact } \\
\text { through the use of resources }\end{array}$ \\
\hline $\begin{array}{c}\text { Litvak S., } \\
\text { Litvak O. [12] }\end{array}$ & $\begin{array}{l}\text { decoupling is an economic phenomenon that } \\
\text { reflects the capacity for economic growth, } \\
\text { which is not accompanied by increased } \\
\text { environmental pressures }\end{array}$ \\
\hline $\begin{array}{c}\text { Sotnyk M.I., } \\
\text { Kulyk L.A. [16] }\end{array}$ & $\begin{array}{c}\text { decoupling is the phenomenon of the gap } \\
\text { between economic development and the } \\
\text { degree of anthropogenic impact on the } \\
\text { environment }\end{array}$ \\
\hline Tur O. [17] & $\begin{array}{l}\text { decoupling is a strategic basis for developing } \\
\text { a green economy that improves people's } \\
\text { well-being and social justice while } \\
\text { significantly reducing environmental risks } \\
\text { and resource consumption }\end{array}$ \\
\hline
\end{tabular}

The results of the examination of the definitions of "decoupling" indicate that the domestic economic literature so far lacks generalized approaches to substantiate the content of this concept.

\section{RESULT AND DISCUSSION}

The most accurate and complete interpretation of it is considered to be an eco-centric approach, which focuses primarily on the environmental component of economic growth, which is primarily related to the human impact on the environment and the conservation of natural resources. Therefore, according to the eco-centric approach under "decoupling" it is necessary to understand changes in the level of existing (expected) environmental threats as a result of economic growth (Fig. 1):

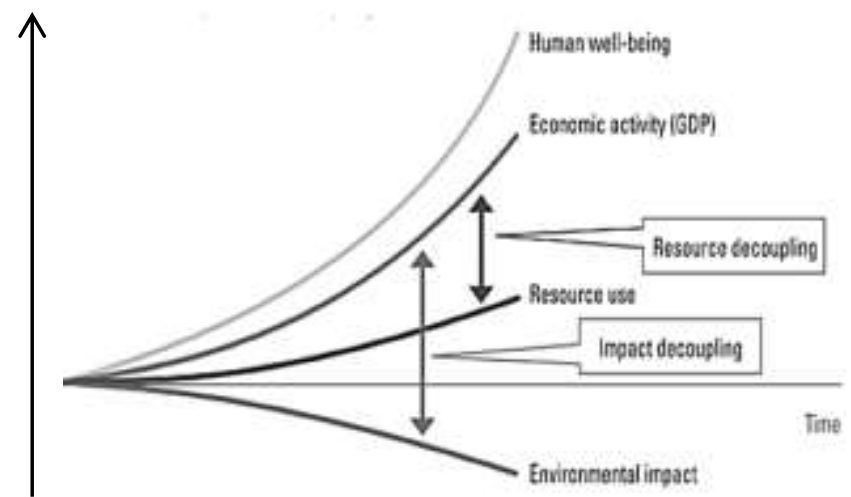

Figure 1: Graphic representation of decoupling in nature load and nature capacity

Source: [8]

Environmental threats according to the results of economic growth are dual and therefore characterized by:

resource decoupling - decoupling on the nature capacity of production (level of use in the production of natural resources);

impact decoupling - decoupling by naturally loaded (the level of impact of production on the environment [12].

Therefore, the Decoupling Index and Decoupling Factor are proposed to evaluate the decoupling effect according to the OECD methodology:

$$
\text { Decoupling Index }=\frac{\left(\frac{E P}{D F}\right)_{\text {ending }}}{\left(\frac{E P}{D F}\right)_{\text {beginning }}},
$$

Decoupling Factor=1- Decoupling Index

Where:

EP (environmental pressure) - an indicator of anthropogenic pressure on the environment (or the amount of consumed resource),

DF (driving force) - economic growth indicators that are typically reflected through macroeconomic indicators, in particular gross domestic product (hereafter GDP), gross value added (hereinafter referred to as GVA) in the ending and beginning periods research [8].

With this method, we have the opportunity to evaluate the decoupling phenomenon in the whole country, and therefore to determine its position in the international rankings of global indices, which should be considered positive. However, this technique is not perfect.

Therefore, it is not without drawbacks. And the most significant of these is the lack of ability to assess the phenomenon of decoupling in the sectors of the national economy, which is, first of all, an obstacle to making clear and prudent, both tactical and strategic decisions by the government to prevent environmental threats, improve the environment and the restoration of natural resources.

We consider it is necessary to expand the list of economic growth indicators by supplementing it with indicators: gross output (at constant prices for a certain year) of a certain industry, net value added, net profit, etc. in order to be able to estimate decoupling in the sectors of the national economy. 
Let's analyze accompanying the decoupling phenomenon in the increase of the gross production of agricultural production in Ukraine during 2009-2018 according to the table. 2 and make sure that the given proposals are appropriate.

Table 2: Dynamics of indicators of economic growth and environmental threats in the agricultural production of Ukraine during 2009-2018 [2]

\begin{tabular}{|c|c|c|c|c|c|c|}
\hline 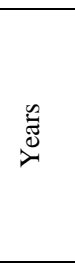 & 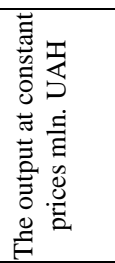 & 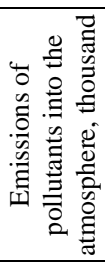 & 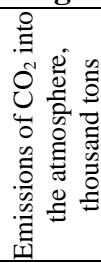 & 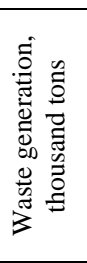 & 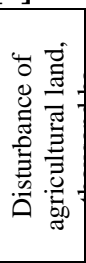 & 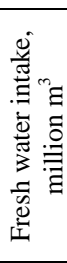 \\
\hline 2009 & 197935.9 & 61.0 & 566.4 & 2761.4 & 0.6 & 2580 \\
\hline 2010 & 187526,1 & 71.0 & 718.1 & 8357.7 & 0.3 & 2565 \\
\hline 2011 & 225381,8 & 72.7 & 790.5 & 12218 & 0.3 & 2889 \\
\hline 2012 & 216589,8 & 80.0 & 673.4 & 10199 & 0.6 & 3107 \\
\hline 2013 & 246109,4 & 89.8 & 974.1 & 10311 & 0.4 & 3427 \\
\hline 2014 & 251427,2 & 77.0 & 775.9 & 8451.4 & 0.1 & 3932 \\
\hline 2015 & 239467,3 & 77.7 & 1110 & 8736.8 & 0.1 & 2989 \\
\hline 2016 & 254640,5 & 81.6 & 878.5 & 8715.5 & 0.3 & 3156 \\
\hline 2017 & 249157,0 & 80.3 & 1099 & 8432.3 & 0.2 & 3196 \\
\hline 2018 & 269408.1 & 82.1 & 1178 & 5968.1 & 0.3 & 3227 \\
\hline
\end{tabular}

For calculations we use the following notation:

$V$ - the volume of gross agricultural production (at constant 2010 prices), million UAH;

$E_{c l}$ - indicator of emissions of pollutants into the atmosphere, thousand tons;

$E_{c 2}$ - indicator of $\mathrm{CO}_{2}$-eq emissions into the atmosphere from stationary sources of pollution, thousand tons;

$E_{c 3}$ - waste generation, thousand tons;

$E_{c 4}$ - arable land, thousand hectares;

$E_{c 5}$ - fresh water intake, million $\mathrm{m}^{3}$.

Hence the Decoupling Index is similar to the formula (1):

$$
\text { Decoupling Index }\left(E c_{i}, V\right)=\frac{K_{E c i}}{K_{v}},
$$

Where:

$\mathrm{K}_{\mathrm{Eci}}$ - the chain rate of growth of environmental threats;

$K_{V}$ - Chain growth rates of gross agricultural output (at constant 2010 prices);

$t$ - year.

Here from:

$$
\begin{array}{r}
K_{E c i}=E_{c i}(\%)-100, \\
K v=V_{t}(\%)-100,
\end{array}
$$

Where:

$E_{c i}, V_{t}$ - the chain growth rate of the corresponding indicator:

$$
E_{c i}=\frac{y_{t}}{y_{t-1}} \cdot 100 \quad V_{t}=\frac{y_{t}}{y_{t-1}} \cdot 100
$$

Where:

$y_{t}$ - the value of the corresponding indicator in the reporting year,

$\mathrm{y}_{\mathrm{t}-1}$ - the value of the corresponding indicator in the previous year.

The Decoupling Factor calculation method does not need to be changed, and therefore this indicator must be calculated by the formula (2).

3 pollutant emissions into the atmosphere $K_{E c l}$, and the chain growth rates of agricultural output (at constant 2010 prices) presented in Table 2, we analyze the decoupling indices, which are summarized in Table 3 and in Fig. 2:

Table 3: Dynamics of indicators decoupling effects of pollutant substances

\begin{tabular}{|c|c|c|c|c|}
\hline $\begin{array}{c}\text { Year } \\
\mathrm{s}\end{array}$ & $\mathrm{K}_{\mathrm{GP}}, \%$ & $\mathrm{~K}_{\mathrm{PS}}, \%$ & $\begin{array}{c}\text { Decoupling } \\
\text { Index }\end{array}$ & $\begin{array}{c}\text { Decouplin } \\
\mathrm{g} \text { Factor }\end{array}$ \\
\hline 2010 & -5.2591 & 16.3934 & -3.1171 & 4.1171 \\
\hline 2011 & 20.1868 & 2.3943 & 0.1186 & 0.8813 \\
\hline 2012 & -3.9009 & 10.0412 & -2.5740 & 3.5740 \\
\hline 2013 & 13.6292 & 12.25 & 0.8988 & 0.1011 \\
\hline 2014 & 2.1607 & -14.253 & -6.5967 & 7.5967 \\
\hline 2015 & -4.7568 & 0.9090 & -0.1911 & 1.1911 \\
\hline 2016 & 6.3362 & 5.0193 & 0.7921 & 0.2078 \\
\hline 2017 & -2.1534 & -1.5931 & 0.7398 & 0.2601 \\
\hline 2018 & 8.1278 & 2.2415 & 0.2757 & 0.7242 \\
\hline \multicolumn{5}{|c|}{ Source:[own calculations] } \\
\hline
\end{tabular}

The conducted calculations make it possible to state that during the period studied economic growth in agribusiness is caused by the use of extensive factors of the development on the basis of outdated resource and consuming technologies, the use of which is a significant eco-destructive factor, which shows the obvious need to reduce the negative impact on the environment [16].

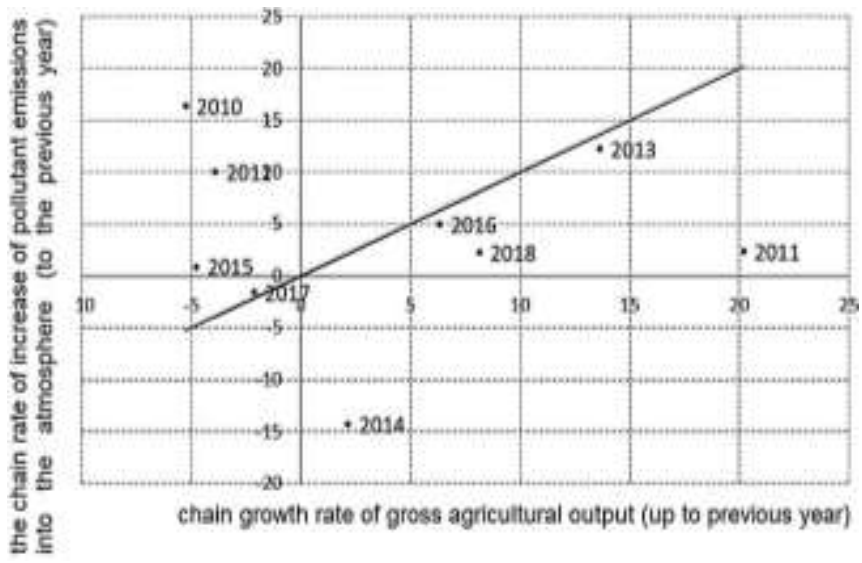

Figure 2: Dynamics of indicators decoupling effects of pollutant substances Source: [own calculations]

By analogy with the study of the previous indicator, according to the results of the comparison of the chain growth rates of $\mathrm{CO}_{2}$-eq emissions into the atmosphere from stationary sources of pollution $K_{c 2}$ and the chain growth rates of the gross agricultural output (at constant prices in 2010) $K_{v l}$, it was established that during 2009-2018, $\mathrm{CO}_{2}$-eq emissions into the atmosphere from stationary sources of pollution are prone to reduction (Table 4 and Figure 3): 
Table 4: Dynamics of indicators decoupling the impact of emissions $\mathrm{CO}_{2}$-eq into the atmosphere from stationary sources of pollution

\begin{tabular}{|c|c|c|c|c|}
\hline $\begin{array}{c}\text { Year } \\
\mathrm{s}\end{array}$ & $\mathrm{K}_{\mathrm{GP}}, \%$ & $\mathrm{~K}_{\mathrm{PS} 2}, \%$ & $\begin{array}{c}\text { Decoupling } \\
\text { Index }\end{array}$ & $\begin{array}{c}\text { Decoupling } \\
\text { Factor }\end{array}$ \\
\hline 2010 & -5.2591 & 26.783 & -5.0926 & 6.0926 \\
\hline 2011 & 20.1868 & 10.082 & 0.4994 & 0.5005 \\
\hline 2012 & -3.9009 & -14.813 & 3.7973 & -2.7973 \\
\hline 2013 & 13.6292 & 44.653 & 3.2763 & -2.2763 \\
\hline 2014 & 2.1607 & -20.346 & -9.4166 & 10.416 \\
\hline 2015 & -4.7568 & 43.111 & -9.0630 & 10.063 \\
\hline 2016 & 6.3362 & -20.884 & -3.2960 & 4.2960 \\
\hline 2017 & -2.1534 & 25.190 & -11.697 & 12.697 \\
\hline 2018 & 8,1278 & 7,1922 & 0,8848 & 0,1151 \\
\hline
\end{tabular}
Source:[own calculations]

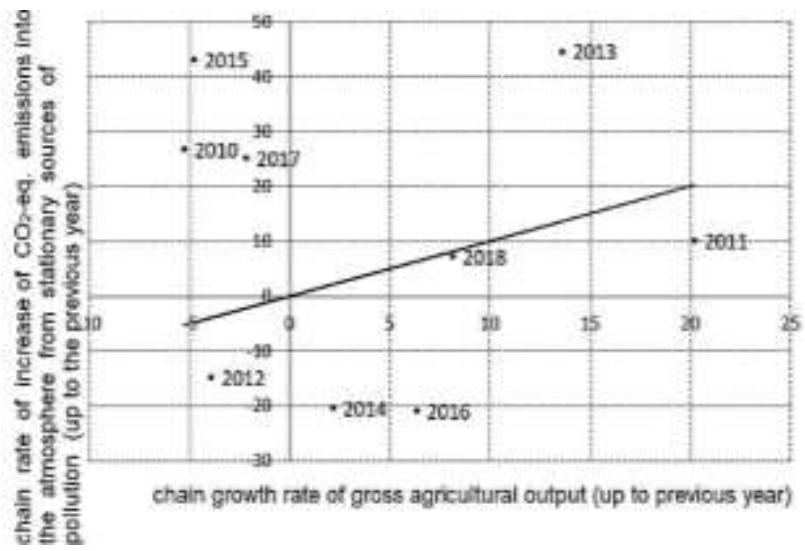

Figure 3: Dynamics of indicators decoupling the impact of emissions $\mathrm{CO}_{2}$-eq into the atmosphere from stationary sources of pollution Source:[own calculations]

The impact of waste generation on the eco-system with an increase in the volume of grosses of agricultural output by comparison of indicators $K_{c 3}$, and $K_{v l}$, and is much lower than in the previous calculations, as evidenced by the calculations presented in Table 5 and Figure 4:

Table 5: Dynamics of indicators decoupling the impact of waste generation

\begin{tabular}{|c|c|c|c|c|}
\hline $\begin{array}{c}\text { Year } \\
\mathrm{s}\end{array}$ & $\mathrm{K}_{\mathrm{GP}}, \%$ & $\mathrm{~K}_{\mathrm{w}}, \%$ & $\begin{array}{c}\text { Decoupling } \\
\text { Index }\end{array}$ & $\begin{array}{c}\text { Decoupling } \\
\text { Factor }\end{array}$ \\
\hline 2010 & -5.2591 & 202.66 & -38.534 & 39.534 \\
\hline 2011 & 20.1868 & 46.193 & 2.2882 & -1.2882 \\
\hline 2012 & -3.9009 & -16.522 & 4.2355 & -3.2355 \\
\hline 2013 & 13.6292 & 1.1000 & 0.0807 & 0.9192 \\
\hline 2014 & 2.1607 & -18.041 & -8.3496 & 9.3496 \\
\hline 2015 & -4.7568 & 3.3769 & -0.7099 & 1.7099 \\
\hline 2016 & 6.3362 & -0.2437 & -0.0384 & 1.0384 \\
\hline 2017 & -2.1534 & -3.2493 & 1.5089 & -0.5089 \\
\hline 2018 & 8.1278 & -29.223 & -3.5954 & 4.5954 \\
\hline
\end{tabular}

Source: [own calculations]

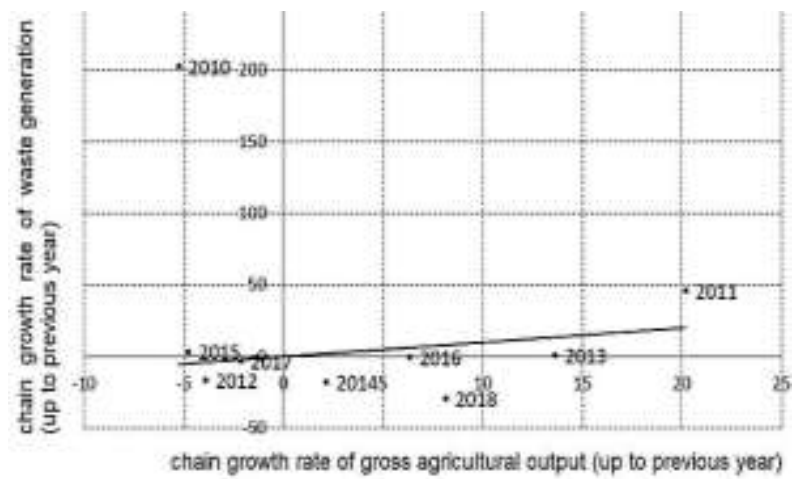

Figure 4: Dynamics of indicators decoupling the impact of waste generation Source:[own calculations]

In turn, the comparison of the chain growth rates of agricultural disturbance volumes $K_{c 3}$ to the chain growth rates of gross agricultural output (at constant 2010 prices) $K_{v l}$, the results of which are presented in Table 6 and Figure 5 , make it possible to ensure that the Government provides a saving attitude to agricultural land:

Table 6: Dynamics of indicators decoupling the impact of disturbance volumes of agricultural land

\begin{tabular}{|c|c|c|c|c|}
\hline Years & $\mathrm{K}_{\mathrm{GP}}, \%$ & $\mathrm{~K}_{\mathrm{AL}}, \%$ & $\begin{array}{c}\text { Decoupling } \\
\text { Index }\end{array}$ & $\begin{array}{c}\text { Decouplin } \\
\mathrm{g} \text { Factor }\end{array}$ \\
\hline 2010 & -5.2591 & -50 & 9.5071 & -8.5071 \\
\hline 2011 & 20.1868 & 0 & 0 & 1 \\
\hline 2012 & -3.9009 & 100 & -25.6348 & 26.6348 \\
\hline 2013 & 13.6292 & -33.333 & -2.4457 & 3.4457 \\
\hline 2014 & 2.1607 & -75 & -34.7102 & 35.7102 \\
\hline 2015 & -4.7568 & 0 & 0 & 1 \\
\hline 2016 & 6.3362 & 200 & 31.5645 & -30.5645 \\
\hline 2017 & -2.1534 & -33.333 & 15.4791 & -14.4791 \\
\hline 2018 & 8,1278 & 50 & 6,1516 & $-5,1516$ \\
\hline
\end{tabular}

\section{Source:[own calculations]}

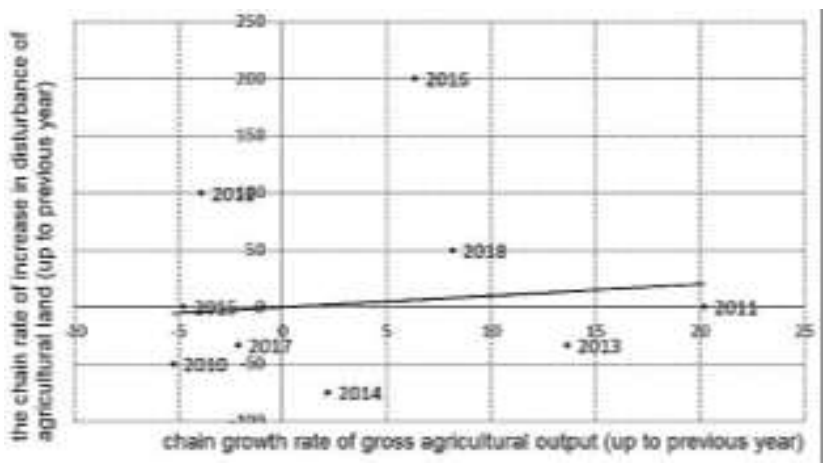

Figure 5: Dynamics of indicators decoupling the impact of disturbance volumes of agricultural land Source:[own calculations]

Attitudes to freshwater intake are characterized by comparisons of indicators $K_{c 5}$ and $K_{v l}$, the results of which indicate that during the period studied the decoupling phenomenon indicates the need for increased attention to the rational use of freshwater (Table 7 and Figure 6): 
Table 7: Dynamics of indicators decoupling the impact of fresh water intake volumes

\begin{tabular}{|c|r|r|r|r|}
\hline Years & $\mathrm{K}_{\mathrm{GP}}, \%$ & $\mathrm{~K}_{\mathrm{AL}}, \%$ & $\begin{array}{c}\text { Decoupling } \\
\text { Index }\end{array}$ & $\begin{array}{c}\text { Decoupling } \\
\text { Factor }\end{array}$ \\
\hline 2010 & -5.2591 & -0.5813 & 0.1105 & 0.8894 \\
\hline 2011 & 20.1868 & 12.631 & 0.6257 & 0.3742 \\
\hline 2012 & -3.9009 & 7.5458 & -1.9343 & 2.9343 \\
\hline 2013 & 13.6292 & 10.299 & 0.7556 & 0.2443 \\
\hline 2014 & 2.1607 & 14.735 & 6.8198 & -5.8198 \\
\hline 2015 & -4.7568 & -23.982 & 5.0417 & -4.0417 \\
\hline 2016 & 6.3362 & 5.5871 & 0.8817 & 0.1182 \\
\hline 2017 & -2.1534 & 1.2674 & -0.5885 & 1.5885 \\
\hline 2018 & 8.1278 & 0.9699 & 0.1193 & 0.8806 \\
\hline
\end{tabular}

Source:[own calculations]

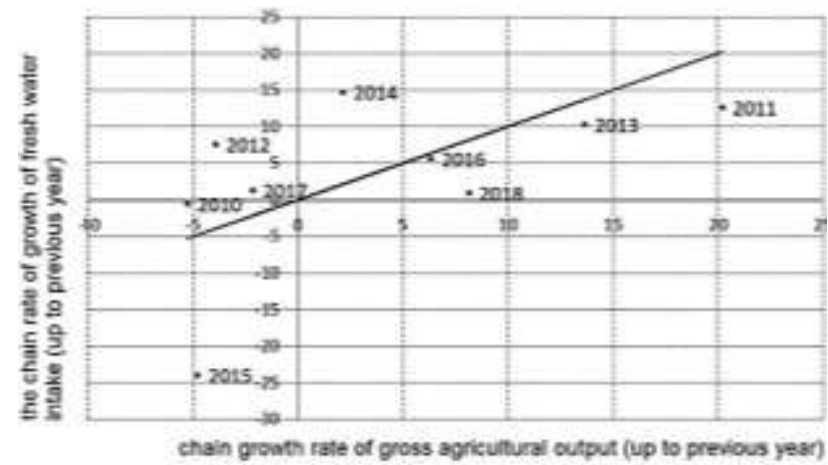

Figure 6: Dynamics of indicators decoupling the impact of fresh water intake volumes Source:[own calculations]

The change in the volume of gross agricultural production is undoubtedly the capital investment aimed at expanding, updating and modernizing the material and technical base of the agricultural business. Therefore, multiple nonlinear dependences are constructed according to the results of correlation-regression analysis of statistics of dynamics of capital investments and output of agricultural production, as well as $\mathrm{CO}_{2}$-eq emissions into the atmosphere from stationary sources of pollution:

$$
\mathrm{Y}=642,47-59732,25 \cdot x_{1}^{-0.5}+1,34 \cdot x_{2}^{0.5},
$$

Where:

$\mathrm{Y}-\mathrm{CO}_{2}$-eq emissions into the atmosphere from stationary sources of pollution, thousand tons,

$\mathrm{x}_{1}$ - capital investment, mln. UAH;

$\mathrm{x}_{2}$ - gross agricultural output (at constant 2010 prices), mln. UAH.

Multiple nonlinear regression coefficients after initial linearization were found by the generalized least squares method in the matrix form.

The schedule of dependence of $\mathrm{CO}_{2}$-eq emissions into the atmosphere on the volume of capital investments in the agrarian business of Ukraine and the volume of gross agricultural production (at constant prices in 2010) is presented in Table 8 and Figure 7.

The obtained coefficient of determination of the model $R^{2}$ $=0,71$ approaches 1 , which indicates sufficient density between the variables.
Table 8: Dependence of $\mathrm{CO}_{2}$-eq emissions into the atmosphere on the volume of capital investments in the agricultural business Source:[own calculations]

\begin{tabular}{|r|r|r|r|}
\hline Years & $\begin{array}{c}\mathrm{CO}_{2} \text { emissions, } \\
\text { thousand tons }\end{array}$ & $\begin{array}{c}\text { Capital } \\
\text { investment, } \\
\text { mln. UAH }\end{array}$ & $\begin{array}{c}\text { Gross } \\
\text { production, } \\
\text { mln.UAN }\end{array}$ \\
\hline 2009 & 566.4 & 8237.9 & 197935.9 \\
\hline 2010 & 718.1 & 10817.7 & 187526.1 \\
\hline 2011 & 790.5 & 16140.9 & 225381.8 \\
\hline 2012 & 673.4 & 18564.2 & 216589.8 \\
\hline 2013 & 974.1 & 18175 & 246109.4 \\
\hline 2014 & 775.9 & 18388.1 & 251427.2 \\
\hline 2015 & 1110.4 & 29309.7 & 239467.3 \\
\hline 2016 & 878.5 & 49660 & 254640.5 \\
\hline 2017 & 1099,8 & 63400,7 & 249157,2 \\
\hline 2018 & 1178,9 & 65059,4 & 269408,1 \\
\hline
\end{tabular}

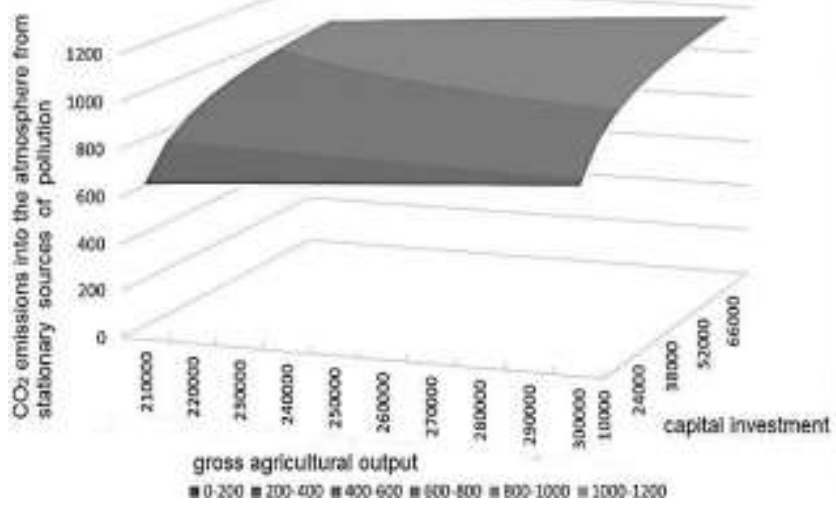

Figure 7: Dependence of $\mathrm{CO}_{2}$-eq emissions into the atmosphere on the volume of capital investments in the agricultural business Source:[own calculations]

The calculated value of the Fisher coefficient according to the sample data $F=8,47$, the critical value of the Fisher coefficient $F_{k r}=4,74$ according to degrees of freedom $k_{l}=7$, $k_{2}=2$ and the level of significance $\alpha=0,05$.

Check according to the Fisher criterion $F>F_{k r}$ showed that with a probability of $95 \%$ can be considered is likely to suggest that the proposed mathematical model is adequate to the statistical data and its application is expedient in assessing environmental threats based on economic growth.

In particular, with the expected increase in capital investment in the volumes foreseen by "AGRO-STRATEGY -2030" to the level of UAH 72.3 billion, the volume of gross agricultural production (at constant 2010 prices) is expected to increase to 293.1 billion $\mathrm{UAH}$ and $\mathrm{CO}_{2}$-eq emissions into the atmosphere from stationary sources of pollution - up to 1143.5 thousand tons.

For fixed projected volume of gross output of agricultural production (at constant 2010 prices) 293.1 billion UAH a graph of the effect of capital investment in the agrarian business on $\mathrm{CO}_{2}$-eq emissions into the atmosphere from stationary sources of pollution has been constructed (Fig. 8).

The reliable zone for this regression is constructed for the significance level $\alpha=0,05$, the critical value of the Student's coefficient according to the table of values is equa $t_{k r}=2,365$. That is, for the prediction value, the confidence interval for the prediction, calculated with reliability $p=95 \%$, is the lower 
bound of the confidence zone of regression $Y=504,21$, and the upper bound of the confidence zone of regression $\mathrm{Y}=1782,82$.

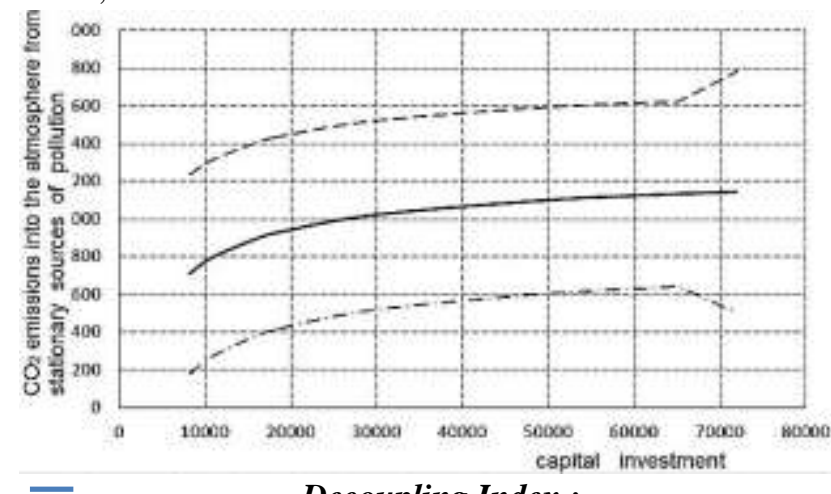

- Decoupling Index;

- The upper bound of the confidence zone of regression

- The lower bound of the confidence zone of regression

Figure 8: Graph of dependence of the impact of capital investments in the agrarian business on $\mathrm{CO}_{2}$-eq emissions into the atmosphere from stationary sources of pollution Source: [own calculations]

\section{CONCLUSIONS}

Thus, according to the results of the conducted research, we come to the conclusion that the list of indicators of the evaluation of the implementation of the state environmental policy, defined by the Law of Ukraine "On Basic principles (strategy) of the state environmental policy of Ukraine for the period up to 2030" from February 28, 2019 No. 2697-VIII [14] needs to be complemented by indicators of a decapitation phenomenon based on the economic growth of both the country as a whole and individual industries, which will enable the government to make clear and well-balanced decisions to increase production, saving attitude to the environment and natural resources to meet current needs of humanity and interests of future generations in the food supply, safe and healthy environment.

\section{REFERENCES}

1. Агробізнес України - 2018/2019. Інфографічний довідник. Available at: https://agribusinessinukraine.com > the-infographics-report-ukrainian-agri... [Accessed 14 Aug. 2019].

2. Agriculture of Ukraine - 2018 (2019). Statistical yearbook. State Statistics Service of Ukraine, Kyiv. Ukraine. Available at: www.ukrstat.gov.ua [Accessed 14 Aug. 2019].

3. Barzhina A.V. The effect of decapling as a tool for analyzing the impact of economic development on the state of the environment in the context of sustainable development/ Economics and Society. 16. (2018). pp. 606-611.

4. Barakat H. The Arab world: Society, culture, and state. California: Univ. of California Press. 1993, pp. 105-117.

5. BIO Intelligence Service, Institute for SE and SERI (2012) Assessment of resource efficiency indicators and targets. Final report prepared for the European Commission, DG Environment. Available at: http://blogs.ec.europa.eu/orep/assessment-of-resource-eff iciency-indicators-andtargets/ [Accessed 14 Aug. 2019].

6. Vatchenko OB, Svistun KO Decapling in the economy the essence, definitions and types / Economic space. 141. (2019). pp. 5-24.

7. Danylyshyn B., Veklic O. The decapling effect as a factor in the relationship between economic growth and environmental pressures/ Bulletin of the National Academy of Sciences of Ukraine. 5. (2008). pp. 12-18.

8. Decoupling Natural Resource Use and Environmental Impacts from Economic Growth / UNEP. 2011. P. 174.

9. Zabelina I.A. The effect of decapitation in the ecological and economic development of regions involved in cross-border interaction. 12. (2019). pp. 241-255.

10. Environmental Impacts from Economic Growth. Available at: https://www.economicshelp.org > ... > economics [Accessed 11 Aug. 2019].

11. Kokovsky L.O. Theoretical and methodological approaches to the implementation of the concept of decapling in regional studies/ Economic and social geography. 3(68). (2013). pp. 121-132.

12. Litvak O.A. Decapling analysis of economic growth and sustainable agricultural land use in the agricultural sector. Scientific Bulletin of Kherson State University. 15. (2016). pp. 40-41.

13. OECD (2001) Environmental Strategy for the First Decade of the 21st Century. Available at:: http://www.oecd.org/dataoecd/33/ 40/1863539.pdf [Accessed 11 Aug. 2019].

14. About the Fundamental Principles (Strategy) of the State Environmental Policy of Ukraine for the Period up to 2030. Law of Ukraine of February 28, 2019 No.2697-VIII. Available at: https://zakon.rada.gov.ua > [Accessed 31 Aug. 2019].

15. Roadmap to a Resource Efficient Europe. Available at: https://ec.europa.eu , about , roadmap , index en [Accessed 11 Aug. 2019].

16. Sotnik M.I., Kulik L.A. Decapling analysis of economic growth and environmental impact in the regions of Ukraine/ Economic Journal - XXI.. 7-8(2). (2014). pp. 60-64.

17. Tour O.M., Mamuk I.V. Methodological approaches to ecological and economic analysis of GDP elasticity under anthropogenic loading/ Economic analysis.1. (2014). pp. 165-170.

18. Thematic Strategy on the sustainable use of natural resources. Communication from the Commission to the Council and the European Parliament. Available at :http://ec.europa.eu/environment/natres/ [Accessed 18 Aug. 2019].
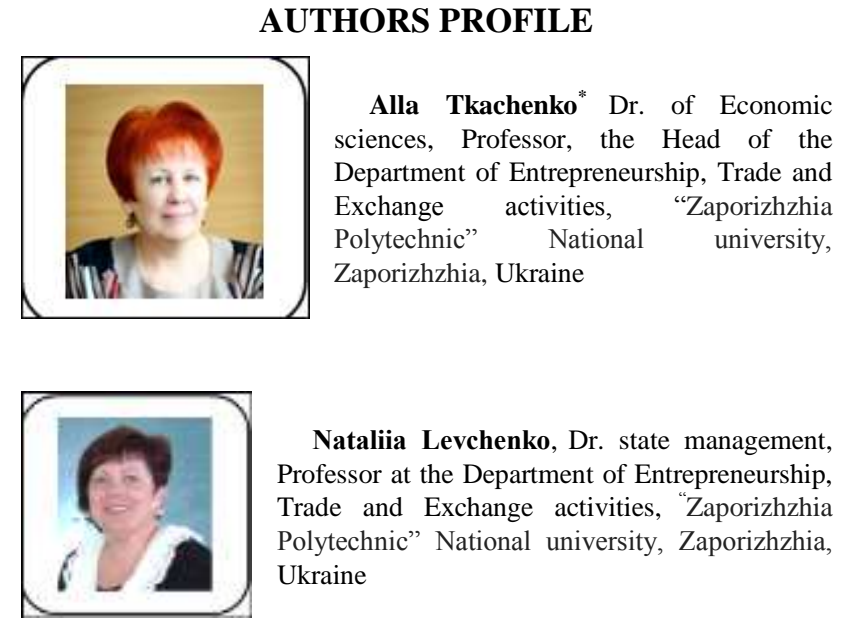

Nataliia Levchenko, Dr. state management, Professor at the Department of Entrepreneurship, Trade and Exchange activities, "Zaporizhzhia Polytechnic" National university, Zaporizhzhia, Ukraine 


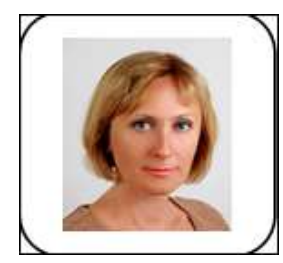

Nataliia Chupryna, Cand. of Economic sciences, Assistant Professor, Dean of the faculty of the Economics, Ukrainian State University of Chemical Technology, Dnipro, Ukraine 